\title{
Determination of Cryptosporidium spp. in Van cats by nested PCR ${ }^{1)}$
}

\author{
ÖZLEM ORUNÇ KILINÇ, ALI BILGIN YILMAZ*, YASAR GÖZ*, \\ CUMALI ÖZKAN ${ }^{* *}$, VURAL DENIZHAN
}

\author{
Özalp Vocational School, Van Yuzuncu Yil University, 65100, Turkey \\ *School of Health, Van Yuzuncu Yil University, 65100, Turkey \\ **Department of Internal Diseases, Faculty of Veterinary Medicine, Van Yuzuncu Yil University, 65100, Turkey
}

Orunç Kilinç Ö., Yilmaz A. B., Göz Y., Özkan C., Denizhan V. Determination of Cryptosporidium spp. in Van cats by nested PCR

Summary

The present study was conducted to investigate the presence of Cryptosporidium spp. agents in cats from the Turkish Van Cat Shelter at YüzüncüYıl University by a modified Ziehl-Neelsen staining method and nested PCR. Individual stool samples were obtained from 30 adult females, 30 adult males and 40 kittens - a total of 100 Van cats were analyzed in the study. A simplified formol-ether concentration method was applied to all samples. The samples were then examined microscopically by a modified Ziehl-Neelsen staining method. As a result of the staining, Cryptosporidium spp. oocysts were identified in stool samples of 3 kittens in the microscopic examination. After that, PCR and nested-PCR were conducted with suitable primers. Nested PCR identified 5 kittens (5\%) as positive. As a result, it was concluded that nested PCR was a superior diagnostic method for Cryptosporidium diagnosis compared with staining methods and that infected cats could be a health hazard for other cats and individuals, since Cryptosporidium spp. agents infect via the faecal-oral route. Therefore, we believe it is necessary to raise the awareness of people in contact with cats.

Keywords: Van cats, Cryptosporidium, Ziehl-Neelsen, nested PCR

The Turkish Van Cat is one of the most important cat species in the world, and it has come under protection in recent years, as the number of these animals is decreasing each year. Van Cats are a great asset for Turkey and the Van province. They are known for their different eye colours, amiability, white silky fur and interest in water (28).

Cryptosporidium species are parasites in the Apicomplexa branch of the protozoa that settle in the human and animal gastrointestinal system and respiratory tract. Cryptosporidium species can infect at least 79 animal species, such as humans, farm animals, birds, reptiles and fish (25). They are commonly observed in childhood, during pregnancy and in immune-compromised individuals, such as AIDS patients. (34). Cryptosporidiosis infections have been reported in 106 countries (13). This parasite has two different genotypes: genotype 1 causes infections in humans only, and genotype 2 causes infections in both humans and animals. The species involved in human

${ }^{1)}$ We are grateful to the Yüzüncü Y1l University Scientific Research Projects Presidency for funding this work. (Project No:2015-SMYO-B125). infections are $C$. muris, $C$. parvum, $C$. hominis, $C$. felis and $C$. canis. Consumption of oocyst-contaminated food or water and direct contact with infected animals or humans cause acute gastroenteritis and diarrhoea in healthy children, but Cryptosporidium parasites can also cause a chronic and life-threatening disease in immunocompromised individuals with AIDS and in malnourished children $(2,15,17)$. Cryptosporidium felis is a cat-specific pathogenic species, which is also found in humans $(1,7,9,18)$.

Primarily microscopic and molecular methods have been used to identify Cryptosporidiosis, which has been scrutinized extensively in recent years and hypothesised to be zoonotic in infected humans and animals $(19,30)$. However, techniques such as IFAT, ELISA and biopsy of infected tissues have also been used. Although different material could be used for the above-mentioned methods, studies demonstrated that the most effective method for diagnosing the disease was faecal screening $(11,31)$. The polymerase chain reaction (PCR) technique was used for the first time in 1991 to identify Cryptosporidium oocysts. (22). This 
study pioneered the use of various PCR techniques in this field. The nested PCR is a more sensitive method than the normal PCR, because the molecular methods determine the agent DNA directly. The nested PCR uses two sequential sets of primers. The first primer set binds to sequences outside the target DNA, as expected in standard PCR, but it also binds to other areas in the template. The second primer set binds to sequences in the target DNA that are within the section that was amplified by the first set (the primers are nested). Thus, the second set of primers would bind and amplify the target DNA within the products of the first reaction. The primary advantage of the nested PCR is that, if the first primers bind to and amplify an unwanted DNA sequence, it is very unlikely that the second set of primers would also bind within the unwanted region. The developed nested PCR method is used in DNA extraction from the oocysts in faeces and water $(3,33,36)$. The objective of the present study was to investigate the agents of Cryptosporidium spp. by the nested PCR method and to reveal their significance for community health.

\section{Material and methods}

Samples. The study material included the faeces samples obtained in May 2016 from 100 Van Cats (30 adult males, 30 adult females and 40 kittens) kept at the Yüzüncü Yıl University Van Cat Research Center. The animals were aged between 6 months and 3 years, and their live weights ranged between 0.5 and $3.4 \mathrm{~kg}$. The faeces samples were obtained from special bed plates used by the cats and placed in stool containers. The containers were assigned protocol numbers. The samples were then taken to Van YüzüncüYıl University Health Vocational School Laboratory, where they were stored at $-20^{\circ} \mathrm{C}$.

Microscopic examination. One hundred fresh stool samples were subjected to modified formol-ether sedimentation and then stained by a modified Ziehl-Neelsen staining method (8). Smears were obtained from the precipitate obtained by the precipitation method. The smears were fixed with absolute methanol for 1 minute and then stained with carbolic fuchsine for 30 minutes. Then they were washed and discoloured with 30\% ethyl alcohol. The slides were washed and stained with methylene blue for 4 minutes, and then washed and dried in the open air. The samples were screened with 100X oil immersion lens for Cryptosporidium oocysts.

Molecular assays. Approximately $200 \mathrm{mg}$ of dissolved stool was poured in $2.0 \mathrm{ml}$ Eppendorf tubes. The freezeand-thaw method was applied to disintegrate oocysts. The tubes were stored for $30 \mathrm{~min}$ at $-20^{\circ} \mathrm{C}$, and then for $5 \mathrm{~min}$ at $+95^{\circ} \mathrm{C}$. These steps were repeated 7 times. Genomic DNA was obtained with a QIAamp mini stool DNA isolation kit according to the manufacturer's instructions. Each tube was vortexed after adding $1 \mathrm{ml}$ Buffer ASL. The vortexed samples were placed in tubes and incubated at $95^{\circ} \mathrm{C}$ for 15 minutes. After incubation, the tubes were centrifuged at $13400 \mathrm{rpm}$ for 1 minute. Inhibit EX tablets were put in $2 \mathrm{ml}$ tubes, the supernatant was added, and the tubes were vortexed for 1 minute and then centrifuged for 3 minutes at $13400 \mathrm{rpm}$. The supernatant from the tubes was pipetted into $1.5 \mathrm{ml}$ tubes and centrifuged at $13400 \mathrm{rpm}$ for 3 minutes to obtain genomic DNA. For detection of the Cryptosporidium phylum, the primer pairs specific to the $18 \mathrm{~S}$ ribosomal RNA gene region and containing Cry 18S-S2, 5'-GGTGACTCATAATAACTTTACGG-3' and Cry 18S-As2, 5'-ACGCTATTGGAGCTGGAAAC-3' and 347-bp gene fragments were amplified. The DNA obtained was used for the nested PCR. Cry18S-S1, 5'TAAACGGTAGGGTATTGGCCT-3', Cry18S-Asl, 5'-CAGACTTGCCCTCCAATTGATA 3' primer pairs and 240-bp gene fragments were amplified by nested PCR (6). PCR was carried out using a thermocycler (Biorad T-100) under the following conditions for both primary and nested analyses. $10 \mathrm{pM}$ of each primer was added in a volume of $50 \mu$ l containing: $20 \mathrm{mM}\left(\mathrm{NH}_{4}\right) 2 \mathrm{SO}_{4}, 75 \mathrm{mM}$ Tris- $\mathrm{HCl}$ (pH 8.8), $1 \mathrm{mM} \mathrm{MgCl}, 0.2 \mathrm{mM}$ dNTP mix, 1.2 Units of Taq DNA polymerase (MBI, Fermentas, Lithuania), and $1 \mu 1$ of template DNA. After 5 minutes of denaturation at $94^{\circ} \mathrm{C}$ in a heat cycle device, heat cycles were performed at $94^{\circ} \mathrm{C}$ for 30 seconds, at $55^{\circ} \mathrm{C}$ for 30 seconds and at $72^{\circ} \mathrm{C}$ for 40 seconds. These heat cycles were repeated 40 times. DNA products of $347 \mathrm{bp}$ and $240 \mathrm{bp}$ were obtained after the final extension at $72^{\circ} \mathrm{C}$, which lasted 10 minutes. For evaluation purposes, $100 \mathrm{bp}$ standard was used, and amplified DNA products were stained with ethidium bromide on $1 \%$ agarose gel and detected under UV light on a gel imager.

\section{Results and discussion}

In this study, 100 stool samples from Van Cats were subjected to modified formol-ether sedimentation and then stained by the Ziehl-Neelsen staining method and examined microscopically. Cryptosporidium oocysts were detected in 3 out of the 40 kittens (Fig. 1) and in none of the adult male and female cats by microscopic scanning. After that, PCR and nested PCR were conducted using suitable primers. Cryptosporidium DNA was detected in stool samples from 5 kittens (aged 3, 5,

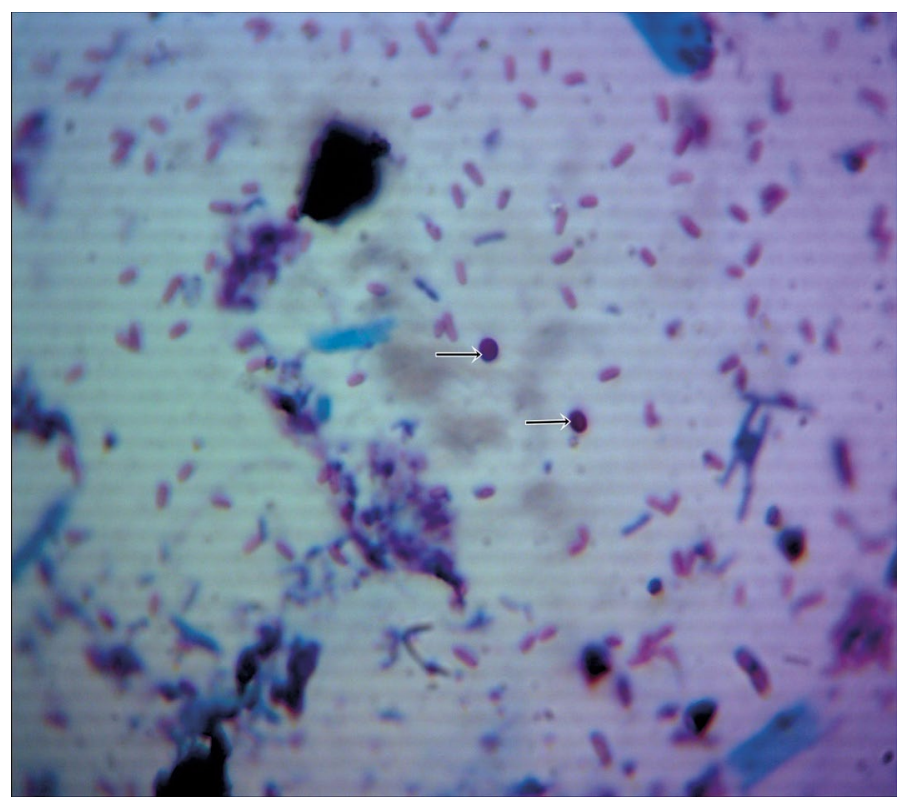

Fig. 1. Cryptosporidium spp. oocysts stained by a modified Ziehl-Neelsen staining method 
5,6 and 6 months) on the basis of poststaining nested PCR results (Fig. 2, 3). These results are shown in Table 1. No clinical signs were observed in kittens infected with Cryptosporidium spp.

Cryptosporidium, an intestinal Tab. 1. Test results $(n=100)$

\begin{tabular}{|l|c|c|c|}
\hline \multicolumn{1}{|c|}{ Number of positives } & $\begin{array}{c}\text { Kitten stool } \\
\text { samples } \mathbf{n = 4 0}\end{array}$ & $\begin{array}{c}\text { Adult male stool } \\
\text { samples } \mathbf{n = 3 0}\end{array}$ & $\begin{array}{c}\text { Adult female stool } \\
\text { samples } \mathbf{n = 3 0}\end{array}$ \\
\hline according to Ziehl-Neelsen staining & $\mathbf{3}$ & $\mathbf{0}$ & $\mathbf{0}$ \\
\hline according to nested PCR & $\mathbf{5}$ & $\mathbf{0}$ & $\mathbf{0}$ \\
\hline
\end{tabular}

coccidian, is an important parasite observed in several species. Cryptosporidium, an intracellular parasite, infects humans, farm animals, birds and reptiles (10, 14). Previous studies reported that morphological detection of Cryptosporidium was difficult, unreliable and time-consuming (12). Furthermore, in another study, it was demonstrated that immunological diagnostic techniques were not more sensitive than microscopic techniques (20).

In several countries, attempts have been made to determine Cryptosporidium prevalence on the basis of faecal incidence. Cryptosporidium spp. was detected in $50(8.3 \%)$ out of 600 cats in the United States, (24), $4(1.3 \%)$ out of 300 cats in Germany (5), $20(3.6 \%)$ out of 507 cats (35) and $23(3.8 \%)$ out of 608 cats (4) in two studies conducted in Japan, $19(8.1 \%)$ out of 235 cats in Scotland (27), 11 (5.4\%) out of 205 cats in Colorado (18), and 10 (3.8\%) out of 263 cats in New York (32). In the present study, Cryptosporidium oocysts were detected in $3(3 \%)$ out of 100 Van cats (60 adults and 40 kittens) examined by a modified Ziehl-Neelsen method. All the stool samples in which oocysts were found originated from kittens. The findings of the present study were consistent with those of the studies conducted in the United States, Germany, Japan, Colorado, Scotland and New York $(5,18,24,27,32,35)$.

PCR was the basis for the development of newgeneration diagnostic methods. For detection of Cryptosporidium in stool specimens, PCR was shown to be more sensitive and more accurate than conventional methods (26). In a study conducted in Australia by both microscopic and PCR techniques on stool from 40 cats, Cryptosporidium oocysts were not observed in a microscopic examination, but PCR gave 4 positive results (23). In a study conducted by the PCR method in Australia, 2 positive results were obtained from 162 faeces samples (30). In North Africa, 8 (32.0\%) out of 50 cats were found to be positive by the PCR method (29). In the present study, the nested PCR method that included a second amplification with nested primers was used to increase specificity and sensitivity in the detection of Cryptosporidium. Nested PCR revealed positivity in $5(12.5 \%)$ out of 40 kittens in this study. Compared with other studies using molecular techniques, this result was similar to the results obtained in Australia $(23,30)$ and lower than those reported from North Africa (29). It was concluded that the difference was caused by the poor hygiene conditions in the study area. As reported in previous studies (6), the fact that the infection was identified in kittens by both techniques used to detect Cryptosporidium indicated that infant and young animals and humans were infected with this protozoon more easily.

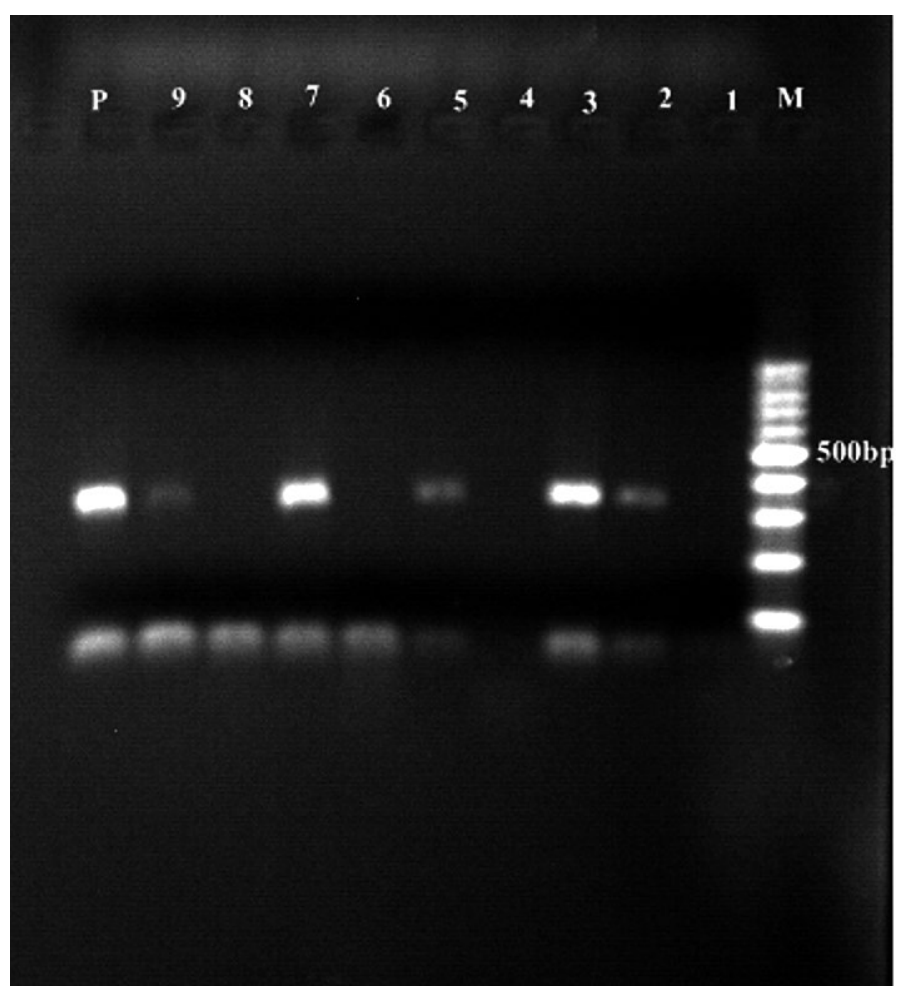

Fig. 2. 1\% agarose gel image of kitten stool nested PCR products $(347 \mathrm{bp})$

Explanations: $\mathrm{M}-100$ bp DNA marker; 1, 4, 6, 8 - negative samples; 2, 3, 5, 7, 9 - positive samples; $\mathrm{P}$ - positive control

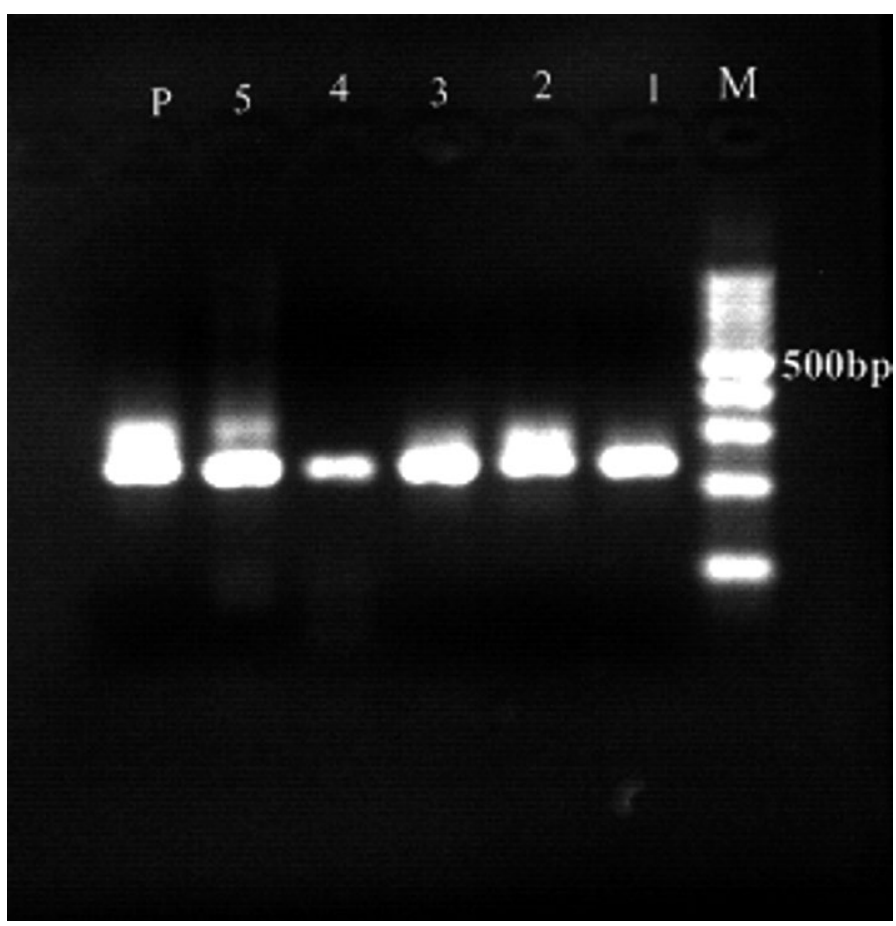

Fig. 3. 1\% agarose gel image of kitten stool nested PCR products (240 bp)

Explanations: $\mathrm{M}$ - 100 bp DNA marker; 1, 2, 3, 4, 5-positive samples; $\mathrm{P}$ - positive control 
Although several studies have been conducted in Turkey to determine Cryptosporidium prevalence in various animal species, there have been few studies on cats. In a study conducted in Van on 40 adult cats and 6 kittens (46 cats in total), Cryptosporidium spp. was determined in all kittens, but none of the adult cats exhibited positive results (16). In a study conducted in Kirikkale by the microscopic method, 1 (1\%) out of 100 cats exhibited positivity (21). In the present study, the agent was identified in $3(3 \%)$ out of 100 cats, which was similar to the finding of the Kirkkkale study. Molecular Cryptosporidium scanning was conducted for the first time in the present study on cats in Turkey.

In cats, as in other animals, Cryptosporidiosis causes signs depending on the immunity of the host. In the present study, no clinical signs were observed in kittens whose feces exhibited positive PCR results. In addition to 3 positive stool samples detected by the Ziehl-Neelsen staining method, additional 2 positive stool samples were detected by PCR, and PCR was considered a more effective method of detecting Cryptosporidium compared to staining methods.

In conclusion, it was found that 5 kittens in the cat sanctuary were infected with Cryptosporidium spp. It has been reported that $C$. felis, the species found in the cats, could also cause disease in humans. Cryptosporidium species could spread by fecal-oral and aerosol routes among animals and humans. Therefore, it is important for public health to know that Cryptosporidium spp. could infect individuals who interact with cats, and these individuals should take precautions.

\section{References}

1. Abarca V. K., Lopez Del P. J., Pena D. A., Lopez G. J. C.: Pet ownership and health status of pets from immunocompromised children, with emphasis in zoonotic diseases. Rev. Chilena. Infectol. 2011, 28, 3, 205-210.

2. Akiyoshi D. E., Dilo J., Pearson C., Chapman S., Tumwine J., Tzipori S.: Characterization of Cryptosporodium melegradis of human origin passaged through different host species. Infect. Immun. 2003, 71, 1828-1832.

3. Amar C., Pedraza-Diaz S., McLauchlin J.: Extraction and genotyping of Cryptosporodium parvum DNA from fecal smears glass slides stained coventionally for direct microscope examination. J. Clin. Microbiol. 2001, 39, 401-403.

4. Arai H., Fukuda Y., Hara T., Funakoshi Y., Kaneko S., Yoshida T., Asahi H., Kumada M., Kato K., Koyama T.: Prevalence of Cryptosporidium infection among domestic cats in the Tokyo Metropolitan District, Japan. Jpn. J. Med. Sci. Biol. 1990, 43, 7-14.

5. Augustin-Bichl V., Boch J., Henkel G.: Cryptosporidial infections in dogs and cats. Berl. Munch. Tierartzl. Wschr. 1984, 97, 179-181.

6. Bairami K. A., Rezaeian M., Zeraati H., Mohebali M., Meamar A. R., Babaei Z., Kashi L., Heydarnezhadi M., Rezaie S.: A Sensitive and Specific PCR Based Method for Identification of Cryptosporidium Sp. Using New Primers from 18S Ribosomal RNA, Iranian. Iranian J. Parasitol. 2011, 4, 1-7.

7. Bukhari Z., Smith H. V.: Effect of Three Concentration Techniques on Viability of Cryptosporidium parvum Oocysts Recovered from Bovine Feces. J. Clin. Microbiol. 1995, 33, 2592-2595.

8. Caccio S., Pinter E., Fantini R., Mezzaroma I., Pozio E.: Human infection with Cryptosporodium felis: Case report and literature review. Emerg. Infect. Dis. 2002, 8, 85-86

9. Casemore D. P.: Laboratory methods for diagnosing cryptosporidiosis. J. Clin. Pathol. 1991, 44, 445-451.

10. Chalmers R. M., Elvin K., Thomas A. L.: Infection with unusual types of Cryptosporodium is not restricted to immunocompromides patients. J. Infect. Dis. 2002, 85, 270-271.

11. De Oliveria Lemos F., Almosny N. P., Soares A. M., Alencar N. X.: Cryptosporidium species screening using Kinyoun technique in domestic cats with diarrhea. J. Feline Med. Surg. 2012, 14, 113-117.
12. Emre Z., Alabay M., Düzgün A., Çerci H.: Comparison of staining and concentration techniques for detection of Cryptosporodium oocyst faecal specimens. Turk. J. Vet. Anim. Sci. 1997, 21, 293-296

13. Fall A., Thompson R. C., Hobbs R. P., Morgan-Ryan U. M.: Morphology is not a reliable tool for delineating species within Cryptosporidium. J. Parasitol. 2003, 89, 399-402.

14. Fayer R.: Biology, [in:] Fayer R., Xiao L. (eds.): Cryptosporidium and Cryptosporodiosis. CRC Press and IWA Publishing. Boca Raton, FL, 2008, p. $1-41$.

15. Fayer R., Morgan U., Upton S. J.: Epidemiology of Cryptosporidium: transmission, detection and identification. Int. J. Parasitol. 2000, 30, 1305-1322.

16. Gatei W., Greensill J., Ashford R. W., Cuevas L., Parry C. M., Cunliffe N. A., Beeching N. J., Hart C. A.: Molecular analysis of the 18S rRNA gene of Cryptosporodium parasites from patients with or without human immunodeficiency virus infections living in Kenya, Malawi, Brazil, the United Kingdom, and Vietnam. J. Ciln. Microbiol. 2003, 41, 1458-1462.

17. Goz Y., Yuksek N., Altug N., Ceylan E., Deger S.: Prevalence of Cryptosporidium infection in Van cats. Indian. Vet. 2005, 82, 995-996.

18. Guyot K., Follet-Dumoulin A, Lelievre E., Sarfati C., Robodonirina M., Nevez G., Cailiez J. C., Camus D., Dei-Cas E.: Molecular characterization of Cryptosporodium isolates obtained from humans in France. J. Clin. Microbiol. 2001, 39, 3472-3480.

19. Hill S. L., Cheney J. M., Taton-Allen G. F., Reif J. S., Burns C., Lappin M. R. Prevalance of enteric zoonotic organisms in cats. J. Am. Vet. Med. Assoc. 2000, 216, 687-692.

20. Iseki M.: Cryptosporidium felis sp. n. (Protozoa: Eimeriorina) from the domestic cat. Jap. J. Parastiol. 1979, 28, 285-307.

21. Kehl K. S. C., Circirello H., Havens P. L.: Comparison of four different methods for the detection of Cryptosporidium species. J. Clin. Microbiol. 1995, 33, 416-418.

22. Korkmaz U. F., Gökpınar $S$., Yıldız K.: Kedilerde Bağırsak Parazitlerinin Yaygınlığı ve Halk Sağlığı Bakımından Önemi. Turkiye Parazitol. Derg. 2016, 40, 194-198.

23. Laxer M. A., Timblin B. K., Patel R. J.: DNA sequences for the specific detection of Cryptosporidium parvum by the polymerase chain reaction. An. J. Trop. Med. Hyg. 1991, 45, 688-694.

24. McGlade T. R., Robertson I. D., Elliot A. D., Read C., Thompson R. C. A. Gastrointestinal parasites of domestic cats in Perth, Western Australia. Vet. Parasitol. 2003, 117, 251-262.

25. McReynolds C. A., Lappin M. R., Ungar B., McReynolds L. M., Bruns C., Spilker M. M., Thrall M. A., Reif J. S.: Regional seroprevalence of Cryptosporidium parvum-specific IgG of cats in the United States. Vet. Parasitol. 1999, 80, 187-195.

26. Moiser D. A., Oberst R. D.: Cryptosporidiosis. A global challenge. Ann. N. Y. Acad. Sci. 2000, 916, 102-111.

27. Morgan U. M., Thompson R. C. A.: PCR detection of Cryptosporidium: The way forward? Parasitol. Today 1998, pp. 241-244.

28. Mtambo M. M. A., Nash A. S., Blewett D. A., Smith H. V., Wright S.: Cryptosporidium infection in cats: prevalence of infection in domestic and feral cats in the Glasgow area. Vet. Rec. 1991, 129, 502-504.

29. Özkan C., Karaca M., Özdal N.: Van Kedilerinin Kulak Uyuzunun (Otodectes cynotis) Topikal Selamectin ile Tedavisi. Turkiye. Parazitol. Derg. 2013, 37, 269-272.

30. Samie A., Tsipa M. A., Tsipa P. B.: The epidemiology of Cryptosporidium in cats and dogs in the Thohoyandou region, South Africa. Afr. J. of Microbiol. Res. 2013, 7, 2510-2518.

31. Sargent K. D., Morgan U. M., Elliot A., Thompson R. C. A.: Morphological and genetic characterization of Cryptosporidium oocysts from domestic cats. Vet. Parasitol. 1998, 77, 221-227.

32. Sears C. L., Kirkpatric B. D.: Cryptosporidiosis and isosporosis, [in:] Principles and Practice of Clinical Parasitology. John Wiley \& Sons Ltd. Press. 2001, p. $139-164$.

33. Spain C. V., Scarlett J. M., Wade S. E., McDonough P.: Prevalence of enteric zoonotic agents in cats less than 1 year old in central New York State. J. Vet. Int. Med. 2001, 15, 33-38.

34. Sturbaum G. D., Reed C., Hoover P. J., Jost B. H., Marshall M. M., Sterling C. R.: Species-specific, nested PCR-restriction fragment polymorphism detection of single Cryptosporodium parvum oocysts. Appl. Environ. Microbiol. 2001, 67, 2665-2668.

35. Tzipori E. E.: Cryptosporidiosis in perspective. Adv. Parasitol. 1998, 27, 63-130.

36. Uga S., Matsumura T., Ishibashi K., Yoda Y., Yatomi K., Kataoka N.: Cryptosporidiosis in dogs and cats in Hyogo Prefecture, Japan. Jpn. J. Parasitol. 1989, 38, 139-143.

37. Xiao L., Bern C., Limor J., Sulaiman I., Roberts J., Checkly W., Cabrera L., Gilman R. H., Lal A. A.: Identification of 5 types of Cryptosporidium parasites in children in Lima, Peru. L. Infect. Dis. 2001, 183, 492-497.

Corresponding author: Ass. Prof. Özlem Orunç Kılınç, Yuzuncu Yıl University, Özalp Vocational School, Van, Turkey; e-mail: ozlemkilinc@ yyu.edu.tr 